\title{
Reason, Law, and Authority in Plato's Crito
}

\author{
Mark Brouwer \\ Wabash College
}

\section{Introduction}

The fundamental problem when interpreting Plato's Crito is how to reconcile two parts of the dialogue that appear to be governed by two, conflicting principles: the first part of the dialogue (Cr 43a-49e) articulates Socrates' commitment to the rule of Reason, the second part of the dialogue $(\mathrm{Cr} 49 \mathrm{e}-$ 54e) articulates Socrates' commitment to the rule of Law. The apparent conflict stems from Socrates' acquiescence in the face of the Laws: Socrates seems to be abandon his previous commitment to Reason and deliberation in favor of dogmatic obedience to the law. The apparent problem is solved by recognizing the common structure of Reason and Law: both depend upon a principle of authority, outside of each, that determines the boundaries only within which Reason and Law are possible. Plato's Crito exemplifies this principle and suggests its implications.

This essay is divided into three parts: Part One features my interpretation of Plato's Crito. Part Two is my discussion some of the relevant scholarship on the Crito; I show that nearly all interpreters agree about the fundamental tension of the dialogue, while misunderstanding its importance. I address only those interpretations that significantly influence my own. The third, and final part of my paper is Preliminary Conclusions. These conclusions are far more speculative than my main argument about the Crito and are intended to indicate broader implications and areas for further research. I have included the literature review primarily for those who wish to situate my interpretation within the recent history of Crito scholarship. While I obviously believe that my interpretation is novel and important, I also believe my account of recent scholarship 
on the Crito is interesting in its own right. Part One includes the full justification for my interpretation of Plato's Crito.

Most interpreters either justify Socrates' obedience ${ }^{1}$ to the law or try to explain away his apparent dogmatism; in both cases, interpreters are forced to reconstruct arguments for why Socrates should or should not remain in prison. The very fact that we must reconstruct these arguments is my clue to thinking about the fundamental tension in a different way: Why does a man so deeply committed to discursive examination fail to examine when speaking with the laws of Athens? The tension is one of competing principles, the principle that reason must always be obeyed, and the principle that law must always be obeyed. As principles, we should not expect to find any straightforward argument for them; rather, we should expect the arguments to proceed from them.

\section{Part One: Reason, Law, and Authority}

It has been frequently and rightly remarked that the Crito is unique among Plato's dialogues insofar as its primary concern is what Socrates ought to do. ${ }^{2}$ Most interpreters assume that Socrates ought to do what seems best to his reason ( $\mathrm{Cr} 46 \mathrm{~b} 3-6)$; thus, most interpretations defend the rationality of obedience or disobedience. On my account, it is not at all obvious that Socrates ought to do what seems best to his reason. On my account, Socrates does not do what seems best to his reason because he does not reason about whether he should obey the laws; he simply obeys the laws. Doubtless, this claim seems counterintuitive to many; after all, does not Socrates articulate and defend his reasons for remaining in prison from 49c to 54c? Is it not the cogency of Socrates' reasons for remaining in prison that have been so thoroughly debated in the scholarship summarized below? My answer to both of these questions is 'no.' Perhaps counter-intuitively I claim that the reasons for remaining in prison, from Crito 49c to54c, are not Socrates' reasons; they are the arguments of the speaking laws of Athens. ${ }^{3}$

${ }^{1}$ Here and throughout, I do not intend to imply anything about the so-called "historical Socrates", nor about Plato's relation to such a person. For my purposes, "Socrates" is a fictional character created and developed by Plato to represent an ideal philosopher. All references to Plato are from the O.C.T. editions; translations are based on Grube / Cooper.

${ }^{2}$ See Metcalf 2004, p53; Harte 1999, p130; and Lane 1998: "The Crito is the sole Platonic dialogue in which Socrates engages in deliberation. I mean this in the Aristotelian sense of deliberating on what to do" (313).

${ }^{3}$ I am indebted to my student, Jacob Stump, for bringing this aspect of my own inter- 
In the dramatic setting of Plato's Crito, Socrates addresses himself in the speaking voice of the laws of Athens. Socrates - in the voice of the laws - asks, "Tell me, Socrates... Do you not by this action you are attempting intend to destroy us, the laws, and indeed the whole city, as far as you are concerned?" (Cr 50a-b) The reasons given for Socrates' remaining in prison hinge upon this question. Over the next four Stephanus pages the laws interrogate Socrates, and Grube / Cooper quite rightly set the laws' arguments in quotation marks to indicate the distinction between Socrates and the laws. I simply assume that Plato intended this distinction, that if Plato wanted Socrates to give his own reasons for remaining in prison he would have done so. Instead, Plato has Socrates conduct an admittedly one-sided conversation with himself where the laws of Athens interrogate Socrates exactly as Socrates interrogates the interlocutors of Plato's dialogues. ${ }^{4}$

The one-sided nature of the discussion between Socrates and the laws of Athens is the key to noticing just how passively Socrates accepts the laws' reasons for remaining in prison. Unlike what Socrates - in other Platonic contexts, most notably the beginning of the Crito itself - normally expects of himself and his interlocutors, Socrates is disengaged and acquiescent in the face of the speaking laws. He simply fails to examine the laws' arguments. The laws give reasons - good ones or bad ones - for Socrates to remain in prison; however, the Crito is unusual among Plato's dialogues precisely insofar as Socrates does not examine these reasons. We may be able to reconstruct what the results of such an examination might have been; but, we cannot deny that Socrates uncharacteristically fails to examine. Since the Crito is uniquely concerned with what Socrates ought to do, I propose that we take the fundamental question of the dialogue as this: should Socrates examine the laws reasons for him to remain in prison, or should he simply accept their conclusion? Should Socrates recognize the authority of Reason and cross-examine the laws; or should he recognize the authority of the speaking Laws and not cross-examine? When posed in this way,

pretation to my attention.

${ }^{4}$ To be clear, I read the Crito as if it included three primary characters: Crito, Socrates and the laws of Athens. I assume that Plato contrives to have the laws cross-examine Socrates for a reason, just as Plato contrives to have Socrates cross-examine Crito in the beginning of the dialogue. I do not assume that the words of Socrates invariably represent Plato's views, nor do I assume that the words of the laws represent Socrates' views. To merely assume that Socrates presents his own reasons in the voice of another is unwarranted neglect of the dramatic structure of the dialogue. Had Plato intended Socrates to give his own reasons for remaining in prison, then he would have done just this. 
the question of what Socrates ought to do becomes a question of whether or not to examine.

We know from the Apology that Socrates was convicted of corrupting the youth and not believing in the gods of the city $(A p 24 \mathrm{~b} 8-\mathrm{c} 1) .{ }^{5}$ Socrates is not surprised that he is convicted, although he seems to consider himself to have been acquitted ( $\dot{\alpha} \pi \mathrm{o} \pi \dot{\varepsilon} \varphi \varepsilon v \gamma \alpha$, Ap 36a7,8). Indeed, he not only considers himself innocent, Socrates says that those who convicted him are in the wrong: "And now away, I being sentenced to death by you, but those men having been sentenced to wickedness and injustice by the truth" (Ap 39b4-6, see also Ap 38c1 -2, 39c1d9). This is sufficient evidence that it is at least possible that Socrates considered his conviction under the laws of Athens unjust. Beyond these specific passages, the Apology as a whole must lead us to believe that Socrates considered himself innocent of the specific charges brought against him; and, thus that Socrates did not agree with the verdict of the Laws in his case. ${ }^{6}$ Yet, in his discussion with the laws, Socrates rejects even asking whether "the city has done injustice to us, and has it incorrectly decided its judgment". ${ }^{7}$ My point is only that there is a real question over the justice or injustice of Socrates' obedience to his sentence; Socrates would have good reasons to suspect that he has been treated unjustly.

${ }^{5}$ In addition to these specific charges, Socrates address earlier charges out of which arose the new charges of Meletus and Anytus. The older charges are that Socrates studies the things of the heavens and below the earth and that he makes the weaker argument the stronger, teaching others to do the same (Ap 19b4-c1).

${ }^{6}$ I believe that the passages I cite from the Apology only serve to emphasize views already implicit in the Crito. Assuming that the views of the character 'Socrates' are at least consistent across the two, the comparison serves to emphasize Socrates' belief in the injustice of his conviction and penalty. The point is not that Socrates in the Crito really believes his punishment unjust; the point is, that the justice or injustice of his punishment is and must be a genuine question; one that he fails even to ask, much less answer. Miller 1996 correctly points out that "it is far from clear what the conclusions the radical reflection on justice, the laws of Athens, and the possibility of therapeutic destructive action will lead to, nonetheless, from the Socratic perspective the questions must be raised and pursued" (133). Please note that I disagree with Miller about Plato's answer to these questions.

${ }^{7}$ (Cr 50c1-2) This important question is uttered by Socrates as the putative, and implicitly rejected, answer to the question of how Socrates should respond to the laws' arguments for remaining in prison. Grube / Cooper translate the same text as follows: "The city wronged me, and its decision was not right.” Socrates asks Crito whether he should respond to the laws' interrogation with this response; Crito says that he should; Socrates remains silent. My basic point is that this is not an issue about which Socrates should remain silent; that he does so prompts the explanation that is this paper. 
Further, Socrates would be right to wonder whether abiding by a potentially unjust sentence would itself be unjust.

Kraut 1984 goes so far as to claim that the Laws "concede that Socrates has been unjustly treated and wronged by Athens" (28). He takes the implied, affirmative response to $C_{r} 50 \mathrm{c} 1-2$ and the laws concluding remarks at $C_{r} 54 \mathrm{c} 2-3$ as evidence of the laws' concession. I doubt that the laws concede as much; ${ }^{8}$ nevertheless, I agree with Kraut (and most other interpreters) that the Crito only confirms the likelihood that Socrates is treated unjustly and wronged by the laws. The crucial question, for my purposes, is whether this likelihood really matters for the question of what Socrates ought to do. Since Socrates so clearly states that one must never return a wrong for a wrong $(C r 49 \mathrm{c} 10 \mathrm{e} 3)$, many interpreters consider it more or less irrelevant to the question of his escape whether Socrates was wronged in his conviction. This way of thinking puts the burden of proof on the justice or injustice of Socrates' potential escape. ${ }^{9}$ Most interpreters take the laws' arguments against and Crito's arguments for escape as their primary interest. I believe the question of the justice or injustice of Socrates' conviction is very relevant to the question of what Socrates ought to do, not because an unjust verdict would justify escape, but because one thing Socrates ought to do is to inquire into the possibility that it would be unjust to remain in prison. ${ }^{10}$

${ }^{8}$ There is no warrant for any implied, affirmative response to $\mathrm{Cr} 50 \mathrm{c} 1-2$ on the part of the laws. On my account, the absence of direct response to the question posed at $\mathrm{Cr} 50 \mathrm{c} 1-2$ is evidence for the fact that it is, for Socrates, an illegitimate question. If Socrates were to ask if the laws were wrong in his case, the laws would (and do) respond that Socrates has no right to ask this question (Cr 50e5-7). The passage to which Kraut refers at $C r 54 \mathrm{c}$,

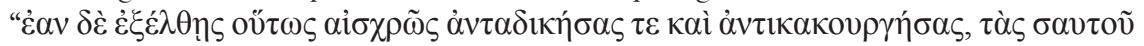

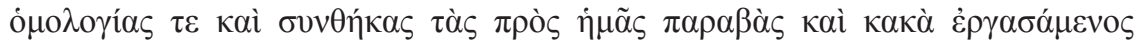

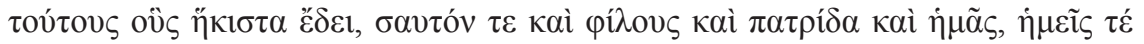

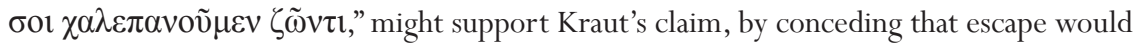
return wrong for wrong, i.e., that the laws wronged Socrates. However, the hypothetical construction (even in the future vivid hypothetical) renders the putative "concession" speculative at best. The laws say "if you escape, then we will be angry with you;" they do not say "if you escape, then you will be returning wrong for wrong." The participles $\alpha \dot{\nu} \tau \alpha \delta ı \kappa^{\prime} \sigma \alpha \varsigma$ and $\alpha v \tau \iota \kappa \alpha \kappa о \cup \rho \gamma \eta ́ \sigma \alpha \varsigma$ definitely modify Socrates' hypothetical escape; however, they could easily be construed to be presenting Socrates' hypothetical reasons for his hypothetical escape. The participles do not necessarily express the views of the speaking laws.

${ }^{9}$ Allen 1980 is again illustrative: "The Crito supposes that laws may be ill-directed or at variance with what is by nature just, and yet still bind to obedience up to the point where they require doing of injustice" (111).

${ }^{10}$ I suggest that Socrates' acquiescence to unjust laws could be an act of injustice; 
Socrates affirms that "it is never right, neither to do injustice, nor to return injustice, nor, even when you are suffering evil, to defend yourself by doing evil in return" (Cr 49d7-9). Prior to this, Socrates had established that life is not worth living with a soul corrupted by injustice (Cr 47e6-48a2). From this, we can infer that the life of the city would not be worth preserving if it had done injustice to Socrates. ${ }^{11}$ Richard Kraut is quite right that "there is no reason for [Socrates] to allow the laws to assume without argument that destroying a city is always wrong" (Kraut 1984, 44). Yet, Socrates assumes without argument that destroying a city is always wrong. Nearly all interpreters of Plato's Crito endeavor to reconstruct the argument that Socrates never makes. I want to draw our attention to what Socrates actually does and does not do.

From the moment the laws of Athens begin to speak, Socrates abandons inquiry. The Laws ask Socrates many (unanswered) questions, they repeatedly implore Socrates to persuade them otherwise (Cr 51b3-4, 51c1, 51e6-52a3),

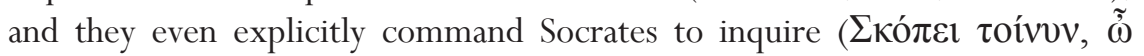
$\Sigma \omega ́ \kappa \rho \alpha \tau \varepsilon \zeta$ Cr 51c6). It must strike us as singularly odd that Socrates does not answer their questions, does not even attempt to persuade them, and does not inquire or examine any of their arguments. At the very end of the dialogue, Socrates simply capitulates by saying to Crito, "know well that I seem to hear just as the Corybantes seem to hear their flutes: this sound of these arguments drones in me and makes me unable to hear the others. But know that if you present to me opinions contrary to these, you will speak in vain." ${ }^{12}$ Even Allen

while this may seem counterintuitive, I believe that it is a possibility that Socrates should not ignore, but does. In this respect, my view of Socrates differs from my view of Dr. M. L. King. I suspect that Dr. King didn't even consider the possibility that his acceptance of unjust punishment could be an act of injustice. The reason is that Dr. King accepted the possibility of unjust laws, Socrates does not. To be fair, I do not really consider the-perhaps important - possibility that Socrates could submit to (genuinely) unjust punishment but not thereby commit injustice; see, e.g., Allen 1980. This possibility probably comes down to the question of whether not acting could be and is in this case an act of injustice. I maintain that Socrates' remaining in prison is an act of obeying the law and, perhaps more importantly, an act of not inquiring about what to do. If this "law" were genuinely unjust (on Socrates' view, a mere "pseudo-law"), then obeying it at least could be committing injustice; thus, it is imperative that Socrates investigate the matter.

${ }^{11}$ This is the gist of Miller's argument for therapeutic destruction of the laws, see Miller 1996, pp130-36.

${ }^{12}$ Cr 54d26. For more on this reference to the Corybantes see Harte 1999, pp11820, Miller 1996, pp121-2, Lane 1998, p330, Weiss 1998, p6, Polansky 1997, p60, Brown 1992, p79, Allen 1980, p82, and especially Metcalf 2004, pp40-46. In general, the former four interpreters take the reference to indicate Socrates' potential disagreement with the 
1980 — who claims that Socrates "chose to die rather than escape because he was convinced by reasoning that it was right to die and wrong to escape; and that reasoning is brought to this conclusion in the speech of the Laws of Athens" (83) — admits that the "dialogue ends on a note of quiet acceptance, with Socrates speaking again in his own voice, affirming the logos of the Laws" (96). The question that animates most of the literature is whether Socrates ought to "quietly accept" the Laws' arguments. This is not the question that interests me. Rather, independent of whether or not Socrates does, doesn't, should or shouldn't "affirm" the Laws' arguments, there is no question that he doesn't reach whatever conclusion he does by having examined the strength of the Laws' argument for himself (see $C_{r} 46 \mathrm{~b} 3$ ). On the contrary, rather than obeying the argument that seems best to his own reasoning ( $\mathrm{Cr} 46 \mathrm{~b} 5-6)$, Socrates obeys the Laws without any cross-examination or inquiry. Most remarkably, Socrates is unable even to hear any other arguments than those of the Laws.

Allen is right that Socrates "quietly accepts" and "affirms" the argument of the laws; with Allen 1980, Bostock 1990, Polansky 1997, and Metcalf 2004 (and against Harte 1999, Miller 1996, Lane 1998, Weiss 1998) I believe that Socrates is right to so affirm. However, I find it extremely hard to accept Allen 1980 and Polansky 1997's claim that Socrates comes to this affirmation based on his own reasoning. Doubtless, Socrates would have come to such a conclusion if he had investigated the matter; but rather than inquire into or examine the arguments for remaining in prison, Socrates merely accepts them. Allen, as most others, spends so much effort reconstructing what Socrates would have argued, that he, as most others, seems blind to fact that "quite acceptance" is hardly rigorous examination. Let me be painfully clear that I side with those who support Socrates decision to remain in prison; I believe Socrates was right to do what he did. I want to insist, however, that we pay careful attention to just what Socrates did and did not do. What Socrates did was to not-examine. The potential reasons for and against the decision to remain in prison have been thoroughly debated in the literature (perhaps overly so); I am particularly interested in the "reasons" for Socrates' decision not to examine the issue. What really deserves our attention now is the fact that all of these reconstructions are merely potential reasons because Socrates gives none. ${ }^{13}$ Again, I believe that the

laws, while the latter four interpreters take the reference to indicate Socrates' agreement. I believe that Metcalf 2004 should have the final word on this perplexing and important reference.

${ }^{13}$ Let me set aside, for the moment, the suggestion of Polansky 1997 and Metcalf 2004 that Socrates' reasons for remaining in prison are really to be found in the first half of the 
Laws present good reasons for remaining in prison; I also believe that these reasons are deeply consistent with arguments that Socrates himself presents earlier in the dialogue; I do not believe however that Plato gives us any indication that Socrates has determined for himself that the reasons presented by the Laws are good ones. This lack of argument and inquiry is particularly shocking in light of a crucial passage in the middle of the Crito. Socrates says:

We must therefore examine whether we should act in the way or not, as not only now but at all times I am the kind of man who listens to nothing within me but the argument that on reflection seems best to me (Cr 46b).

Socrates invokes this imperative always to inquire in response to Crito's most potent "argument" against remaining in prison.

Interpreters (with the exception of Metcalf 2004) too often underestimate the importance of Crito's speech at $C r$ 45c5-46a8. I believe that in this passage Crito presents five, potentially good reasons for Socrates to escape: (1) not to escape is unjust ( $\left.C_{r} 45 \mathrm{c} 5-8\right)$; (2) not to escape would betray Socrates' sons and his duty as a father $(\mathrm{Cr} 45 \mathrm{c} 8-\mathrm{d} 6)$; (3) not to escape would be to choose the easy as opposed to the good and courageous thing to do (Cr $45 \mathrm{~d} 6-8)$; (4) not to escape would bring shame upon Socrates and his friends (Cr 45d8-e1); (5) not to escape would be an act of cowardice $(C r 45 \mathrm{~d} 8-46 \mathrm{a} 4)$. The first reason alone demands Socrates' consideration, given his instance on never doing injustice (Cr 49b3-c12). Yet, Socrates never directly examines any these arguments for escape. Crito's sixth, final, and most potent, "argument" for escape is that the time for discussion is over; Socrates must stop deliberating in order to act now, before it is too late. As Crito states:

Take counsel with yourself, or rather the time for counsel is past and the decision should have been taken, and there is no further opportunity $[\mu \tilde{\alpha} \lambda \lambda$ ov $\delta \dot{\varepsilon}$ ov̉ $\delta \varepsilon \dot{\varepsilon} \beta o v \lambda \varepsilon v ́ \varepsilon \sigma \theta \alpha \imath$ č $\tau \imath$

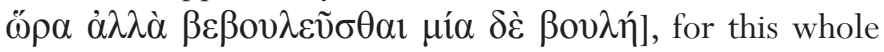
business must be ended tonight [ $\delta \varepsilon \tilde{\imath} \pi \varepsilon \pi \rho \tilde{\alpha} \chi \theta \alpha 1]$. If we delay now, then it will no longer be possible; it will be too late. Let me persuade us on every count, Socrates, and do not act otherwise (Cr 46a).

dialogue. In the end my conclusion will look somewhat like these; for the moment, it is crucial to notice the dramatic interaction between Socrates and the Laws. 
Crito's suggestion is less an "argument" than an injunction to stop all argument in order to act. The subtle juxtaposition of verb tense clearly makes this an injunction from temporal or political expediency. The potency of this injunction is due to its immediate plausibility: it seems that there may be times when we must act in the absence of definitive deliberations or arguments. Indeed this is one of the primary implications of my interpretation of Plato's Crito. ${ }^{14}$ Permit me to suggest what I take to be obvious: It is the very the very essence of political life that we must often act in the absence of definitive reasons for doing so. The point is that in discursive, political arguments there always remains a potential objection to consider, a rational but unconvinced dissenter, and whole host of relevant, unanswered questions. Thus, any political decision is a decision to act in spite of the necessarily unfinished investigation into the reasons for and against doing so.

Is it even possible to argue against (or for) the decision that the time for argument has passed and action must proceed? If the answer is no (and I believe it is), then Socrates' response to Crito's injunction must be understood, not as an argument, but as a counter-injunction. Crito maintains that the time for argument has passed; Socrates maintains that there is no such time. Socrates' response to Crito's injunction is that it is always best to deliberate prior to action (see also Cr 48e4), even presumably if this deliberation forestalls action, in this case the action of saving Socrates' life. Socrates is very explicit that his own, competing principle obtains "not only now but always" (ov̉ vข̃v $\pi \rho \tilde{\omega} \tau$ ov

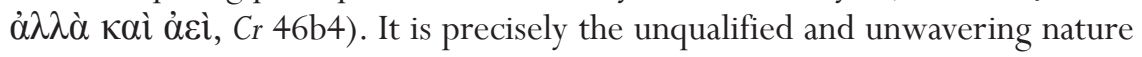
of Socrates' counter-imperative that makes his failure to examine that laws reasons for remaining in prison so conspicuous.

Socrates states the principle - according to which he commits himself al-

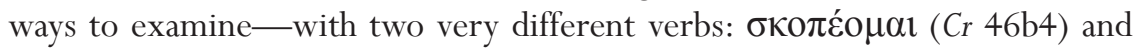

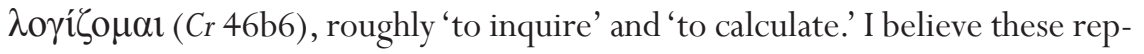
resent two very different senses of the concept 'to reason;' the former more general, the latter more specific. I suggest that the conclusion of Republic VI provides an adequate articulation of these two different senses of reason, or thinking. Inquiry is the general, upward movement of thought toward first principles called nous; calculation is the specifically discursive or deliberative argumenta-

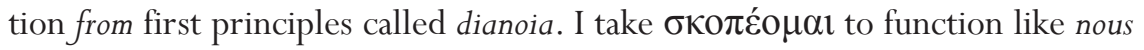

${ }^{14}$ In the end, Socrates agrees with Crito that the time for argumentation has past; he disagrees with Crito about what he should do in light of this political necessity. When Socrates stops arguing he obeys the speaking laws, not Crito. 
and $\lambda \mathrm{o} \gamma \mathbf{i} \zeta \mathrm{o} \mu \alpha \mathrm{l}$ to function like dianoia. The demand to inquire more generally is not the imperative to reason discursively. Doubtless, some sort of inquiry was needed for Socrates to decide not to cross-examine the speaking laws; I suggest that this general sort of thinking is at least analogous to nous. The sort of thinking that led Socrates to obey without examination was not deliberative or discursive examination, dianoia. ${ }^{15}$.

The imperative always to obey "what seems best to [his] reasoning $[\lambda \circ \gamma 1 \zeta o \mu \varepsilon \dot{\varepsilon} \nu \omega]$ " only functions as an effective counter to Crito's imperative to

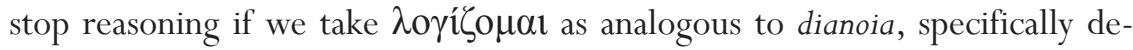
liberative reasoning. ${ }^{16}$ In this context, the specifically "logical" or discursive aspect of Socrates' unyielding commitment to philosophical examination stands in striking contrast to his acquiescence in face of the laws. That is, Socrates' principle always to do what seems best to his reasoning rules-out his absolute and unargued obedience to law. Socrates' counter to Crito's imperative is deeply consistent with Plato's Socrates, in general. It should surprise no one that Socrates claims always to do what seems best insofar as it is the outcome of discursive examination. It should surprise everyone that he does not conduct such an investigation of the laws' arguments for remaining in prison.

The most profound problem of the Crito is that when interrogated by the Laws, Socrates stops arguing. He never posses so much as a question, much less an objection to the Laws. ${ }^{17}$ Socrates is uncharacteristically silent in his "acceptance" of the Laws' arguments. Socrates' silence is all the more troublesome given the evidence that Socrates considered himself innocent and considered those who legally convicted and sentence him as committing injustice; Socrates' silence is most troublesome because he never addresses any of Crito's five, potentially good arguments for escape. The single most pressing question

${ }^{15}$ The more general sense of reason might be helpfully identified with Socratic elenchus, where elenchus - while essentially discursive - is far broader than deductive or inductive refutation; for my understanding of Socratic elenchus see [reference omitted for Blind Review]; I take my understanding to be generally in line with, for example, Metcalf 2004, Polansky and Carpenter 2002, Scott 2002. Inquiry and elenchus include ad homimen arguments and inquiry into first principles.

${ }^{16}$ I assume without argument that dianoia, in Republic VI is more than merely mathematical or strictly deductive reasoning. The downward movement of thought in the Republic includes all sorts of discursive argumentation.

${ }^{17}$ There is one exception that proves this rule. At 52a5-6 Socrates says "Then if I would say 'On account of what, indeed?', then in like manner they would justly attack me..."The inclusion of $\delta 1 \kappa \alpha i ́ \omega \varsigma$ indicates that Plato never means Socrates' only question to express doubt concerning the justice of the Laws. Cf Brown 1992, p13. 
that demands Socrates' examination is this: Might it be unjust for Socrates to remain in prison? I suggest that we can explain Socrates' failure to examine this question by carefully interpreting the very first words spoken by the laws of Athens:

If, as we were planning to run away from here, or whatever one should call it, the laws and the state came an confronted us and asked: "Tell me, Socrates, what you are intending to do? Do you not by this action you are attempting intend to destroy us, the laws, and indeed the whole city, as far as you are concerned? Or do you think it possible for a city not to be destroyed if the verdicts of its courts have no force but are nullified and set at naught by private individuals?" What shall we answer to this and other such arguments? For many things could be said, especially by an orator on behalf of the law we are destroying, which orders that the judgments of the courses shall be carried out ( $\mathrm{Cr} 50 \mathrm{a}-\mathrm{c}$, Grube).

Laws would not be laws if they "have no force."The laws are clearly suggesting, or at least Socrates clearly thinks they are saying that escaping from prison would destroy the principle "that the judgments of the courts shall be carried out." Some try to distinguish between a particular judgment of the court and the principle that laws ought to be obeyed; however, the text is clear that the law in question "orders that the judgments of the courts shall be carried out" ( $\tau$ ov

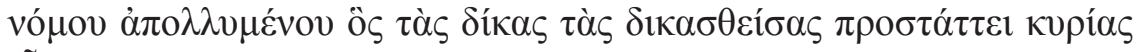
Eivol, Cr 50b7-8). Thus, in addition to asking Socrates whether he wants to destroy the city, the laws effectively demand that they always be obeyed, because disobeying them would be to deny the principle of law; or, what amounts to the same thing, disobeying a "law" would be to deny that it is a law.

The principle that laws must be obeyed is a meta-law, a law about laws. A constitution is a meta-law and it is easy to see how destroying a constitution might be to destroy a political community. The meta-law establishes the necessary conditions for the possibility of law in the same way that the principle that reason is the best way to proceed establishes the conditions for the possibility of discursive inquiry. Understood in this way, the laws' principle is like Socrates' principle that it is always best to act on the basis the best argument ( $\mathrm{Cr} 46 \mathrm{~b} 3-6)$. These principles are alike just insofar as argument and deliberation proceed from them; hence, it is hard to imagine any argument for them, or so I shall argue next. First, we must note that Socrates explicitly considers and rejects the pos- 
sibility of asking a crucial question immediately concluding the previous citation: "[s]hall we say in answer, '[t]he city has done us injustice and it judgment was not right.' Shall we say that, or what?' (Cr 50c1-2). While Crito answers Socrates in the affirmative, Socrates seems utterly to disregard the question. Why? The answer lies in the implicit assumption that the laws are always just, just as Socrates must always inquire.

The assumption that the laws are necessarily just is the crucial premise that justifies Socrates' failure to inquire about the justice or injustice of remaining in prison. This premise is considered "very dubious" by Bostock 1990. His reconstruction of the premise is as follows: "(i) The law that verdicts should be carried out is fundamental to the whole system of laws. Hence (ii) whoever attempts to disobey this law is attempting (for his part) to destroy the whole system of laws" (Bostock 1990, 2). Throughout the article, Bostock treats (i), the fundamental law, as a particular law; and so, disobeying this particular law would be to destroy the laws. Likewise, Kahn 1989 says: "the claim that Socrates intends to destroy the city is plausible only because of the particular law he would be violating." Kahn's account of this "particular law" is "the law that judgments of the court must be carried out" (34-5). Yet, if the "law" that laws ought to be obeyed were a particular law, then would not the question remain as to whether this particular law is just?

Both Kahn and Bostock never really consider the possibility that intending to disobey a verdict would, itself, entail the rejection of the principle of law: laws must be obeyed. ${ }^{18}$ The premise or principle that laws must be obeyed is not itself a particular law; it is law about law or a meta-law. Kahn comes closest to this realization when, following Allen 1980, he says that "what is at stake is not a particular law but the principle of effective legality, any attempt to violate this law would imply an attack on the principle of legality and hence on the existence of the city as a civilized society" (Kahn 1989, 37 emphasis in original). According to Kahn the argument for why escape would destroy the city and its laws "works effectively...only for the violation of a fundamental principle of legality and not for disobedience to any ordinary law" (Kahn 1989, 38). Kahn never seems to notice that the "law that judgments of the court must be carried out" just is this fundamental principle of legality, and hence it is not a particular law.

${ }^{18}$ To be fair, Kahn 1989 considers and rejects the idea of total obedience to the law as philosophically unsalvageable (39-40). This essay is my attempt to "salvage" the principle that law must be obeyed. 
The meta-law, that law must be obeyed, is like the definition of law; more precisely, the meta-law articulates the necessary conditions of law. ${ }^{19}$ Let us assume that it might be unjust for Socrates to remain in prison, based upon the likelihood that his conviction and sentence were unjust. There is no doubt that Socrates believes that it is always unjust to do injustice, or always wrong to do wrong ( $C r$ 48d7-9) because doing wrong harms the soul and, obviously, one must not harm one's soul. Therefore, if Socrates must not obey an unjust "law" and if Law must be obeyed, the obvious question is whether an unjust law even is a law. The answer must be no. We have two fundamental definitions, (a) laws are things one must do, and (b) unjust actions are things one must not do. It follows that "unjust law" is self-contradictory. An "unjust law", for Socrates, would be something that one must do and must not do, at the same time and in the same respect. To grant the possibility of an unjust law is to believe a contradiction. Socrates refusal to believe this contradiction entails that "unjust laws" are impossible; ${ }^{20}$ therefore, obeying the law will always be best for his soul.

The way in which the principle of effective legality is not an ordinary law is directly analogous to the way that the principle always to examine $\left(\mathrm{Cr}_{4} 46 \mathrm{~b} 3-6\right)$ is not the result of an examination. The Socratic principle that argument is always the best way to proceed is not, and cannot be, the result of any straightforward argument (Phd 88c-91c, notwithstanding). Likewise, the principle that laws must be obeyed is not, and cannot be, any ordinary law. The latter is a law about law, or a meta-law; the former is the result of an argument about argument, or a meta-argument. The most profound problem of the Crito is thus a case of competing principles: either argument must always be obeyed or law must always

${ }^{19}$ Just as the Socratic principle of examination (Cr 46b3-6) articulates the necessary conditions of examination, namely that one ought always examine. Polansky 1997 claims that the first half of the dialogue ( $\mathrm{Cr} 43 \mathrm{a}-48 \mathrm{~b})$ "emphasizes the very conditions of philosophical discussion;" it does so by "[defending] against skepticism about the worth of argument and [justifying] Socrates' personal commitment to listening to the argument that seems best" (60).

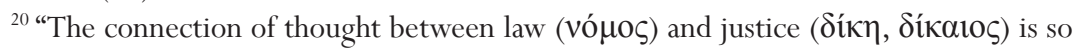
close in Greek that the two concepts are typically thought of a coextensive. Although it is logically possible to express in Greek the idea that Socrates could commit injustice by obeying the law, this idea is wholly alien to the way vó $\mathrm{o}_{\mathrm{S}}$ is conceived not only in the Apology and the Crito but in much of Greek thought" (Kahn 1989, 31-2). Myles Burnyeat once said that he is not aware of one instance in classical Greek of the notion of "unjust law." I thank Antonis Coumondouros for finding the exception that proves this rule: Aristotle's Politics 1282b9-13. My essay provides the sketch of an explanation as to why the notion of "unjust laws" was "wholly alien" to Plato and ancient thought, in general. 
be obeyed. The first part of the Crito is premised on the rule of reason; the second part of the Crito is premised upon the rule of law. The fundamental problem is how to reconcile the dialogue and these two competing principles, how to reconcile Socrates' commitment to examination with his failure to examine.

The first step in solving this problem of competing principles may be to realize that Socrates failure to examine the justice of the laws' decision in his case is entailed by the principle of effective legality. The laws claim that merely to intend to escape would destroy the laws: "Tell me, Socrates, what you are intending to do? Do you not by this action you are attempting intend to destroy us, the laws, and indeed the whole city, as far as you are concerned" (Cr 50a8-b2)? Given that Socrates undoubtedly believes that one must never commit injustice ( $\left.C_{r} 49 \mathrm{~b} 3-\mathrm{c} 12\right)$, any examination of the possibility of escape entails that the justice of the laws' verdict is a question. Such a question entails the rejection of the principle of legality, that laws must always be obeyed because they are necessarily just. Thus, the impossibility of "unjust laws" carries enormous explanatory power for the fundamental problem of why Socrates never investigates whether the laws have done him injustice.

The principle that explains Socrates' failure to question the justice or injustice of his conviction and sentence is none other that the principle that one must believe that that the laws are necessarily just (the meta-law); that the laws are not necessarily just (the presupposition of any inquiry into the justice of the laws) is impossible. To inquire into the justice or injustice of the laws' decision and to accept the principle of effective legality is to believe a contradiction, namely that the laws can and cannot be unjust. Socrates indicates the importance of consistency immediately prior to the introduction of the laws. Indeed, consistency provides the very context to the principle that it is always wrong to do wrong. Socrates asks Crito:

So the consider very carefully whether we have this view in common, and whether you agree, and let this be the basis of our deliberation, that neither to do wrong nor to return a wrong is ever correct, nor is doing harm in return for harm done. Or do you disagree and do not share this view as a basis for discussion? (Cr 49d5-9).

Socrates considers this principle the foundation of all deliberation; he says that agreement to this is a necessary condition for debate. Indeed, he claims that those who accept this principle and those that don't have nothing in common, they have no way to deliberate and are forced to merely disdain one another's 
deliberations (Cr 49d2-5). While this principle certainly has moral implications, its most important implication here is logical, or perhaps metaphysical. The principle to which Socrates insists Crito must agree in order even to begin to deliberate is that wrong actions are always wrong actions; or, that one action cannot be both wrong and not wrong. Clearly, anyone who rejected the principle that wrong actions are wrong would be an impossible interlocutor for argumentative deliberation; Socrates would merely disdain such views because he would be unable to argue for or against them. The fundamental principle is the principle that Crito agree with himself, that he abide by something like the principle of non-contradiction.

It is well known that the terminology of deliberative principles is the same as the terminology of political rule: $\dot{\alpha} \rho \chi \eta ்$ and the verb ö $\rho \chi \omega$. The principle of non-contradiction, the rule of reason and the rule of law are all $\alpha \rho \chi \alpha i$. I cannot put it less vaguely, nor can I be more convinced that the fundamental principle according to which Socrates leads his entire life of deliberation and action is the principle of principles, the meta-principle that Socrates ought to be ruled, that his life ought to have some principle that guides and orders his soul. In normal situations of Socratic examination, Socrates is ruled by the principle articulated at Crito 46b: Socrates is the sort of man who obeys nothing but the conclusions of what seems to him the best argument. In the exceptional situation, in which Socrates stands face-to-face with the speaking laws of Athens, he is ruled by the principle that laws must be obeyed because they are necessarily just.

From here, it is a short step to the reconciliation of the first part of the dialogue, the rule of reason, with the second part of the dialogue, the rule of law. The solution is to see the consistency in being ruled. There must be some principle or rule outside discursive examination that establishes that discursive examination is the proper way to proceed; there must be some principle or rule outside the law that establishes that law ought to be obeyed. Thus, Socrates' "defining commitment" (Metcalf 2004, 59) is to be ruled by reason or law; this rule is a principle of authority common to reason and law.

\section{Part Two: Interpretations of the Crito}

My attempt to understand the Crito in terms of some fundamental tension - roughly dividing along the two halves of the dialogue - and a potential resolution of this tension is hardly unique. I believe the quantity and quality of recent scholarship on the Crito can be explained by a relatively recent turn to thinking about the Crito as a whole dialogue. For many years interpreters 
focused on particular arguments in the Crito - the arguments presented by the Laws, or the argument for never doing wrong - or, at best, the consistency of these arguments with particular passages in the Apology. More recently, in line with broader trends in Plato scholarship, interpreters have focused on the whole dialogue as a dialogue; this shift in focus raises new questions and rightly demands that interpreters think about the first and the second parts of the dialogue together.

The most useful way to think about the current work on the Crito is, roughly, to separate those interpretations that agree with and support Socrates' decision to remain in prison from those that want to explain away Socrates' ostensibly dogmatic obedience to the laws of Athens. If I am right that the central tension of the Crito stems from competing principles, the principle of reason and the principle of law, then this tension explains the two sorts of interpretation: some interpreters want Socrates to remain fundamentally committed to the rule of reason; these usually explain away Socrates' ostensible obedience to the laws of Athens. Other interpreters want Socrates to remain fundamentally committed to the rule of law; these usually explain away any conflict by showing that Socrates is and ought to be reasonably persuaded by the argument for remaining in prison, spoken by the laws of Athens. ${ }^{21}$

${ }^{21}$ Metcalf 2004, p37n3 considers this the "common view." Other representatives of this view are Woozley 1979, Woozley 1980, Brown 1992, Bostock 1990, and Kahn 1989; these latter two will receive special attention below. In addition, Blyth 1995, Blyth 1996, Metcalf 2004, and Polansky 1997 defend similar conclusions for perhaps different reasons. Dougal Blyth deserves special mention because he illustrates the weakness of my admittedly simplistic schematic. Unlike those who explain away Socrates' obedience, Blyth 1995 and 1996 argue that obedience is genuinely warranted in Socrates' case: "because of his education and because of the fact that it would be deliberate, to remove himself unjustly from the state's justice would be (impossibly) to give himself over to his own necessary and justified absolute moral self-condemnation. As Socrates puts it, it would be to 'ruin and maim that which becomes better by justice and is destroyed by injustice' (47d3-5), without which, he and Crito have agreed, life is not worth living" (Blyth 1995, 66-7). To this extent, Blyth follows the "common view" in maintaining that Socrates does what Reason commands by remaining in prison: "the only kind of good which can escape the point of view of the law is that of autonomous reason...the interests of the city, depending on the laws, are protected by the philosopher's defence of the authority of law" (Blyth 1996, 13-14). Yet, Blyth's parenthetical remark, "impossibly," reveals something different about this justification of Socrates' obedience to law. To paraphrase after my own purposes, for Blyth 1995 Socrates escaping from prison would be tantamount to Socrates, per impossible, denying he is Socrates; “Socrates' capacity to philosophize is not the greatest good for him independent of his relations with the city of Athens, with which he could satisfy himself in exile. Phi- 
Miller 1996 is representative of interpretations of the former sort - ones that attempts to explain away Socrates' ostensible obedience because it conflicts with his commitment to the rule of reason. According to Miller, Socrates' own view is that the laws may need to be destroyed for the good of the city; ${ }^{22}$ Socrates suppresses this view in favor of presenting the view of the many through the oratorical voice of the laws: "Socrates in effect invokes the perspective of the many to construct the most intelligible and effective defense possible of the philosopher's commitment to justice" (Miller 1996, 133-4). Basically, since Crito has proven himself unable to understand the genuinely philosophical position, Socrates - in the voice of the laws - presents a deception, one "intelligible" to Crito and "effective", and producing long-term benefits. Socrates "suppresses inquiry in the short term in order to preserve and even occasion it in the long term” (Miller 1996, 134). For Miller, "the Laws proceed precisely as an 'orator' (50b)... Socrates, in first constructing their oratory, does indeed suppress his own very different perspective” (Miller 1996, 133). Thus, for Miller, Socrates' commitment to the rule of Reason is suppressed and Socrates' ostensible obedience to the laws of Athens is explained away as a mere oratory.

Miller admits that "the costs of this strategy seem impossibly high: Socrates both suppresses inquiry and sacrifices his own life” (Miller 1996, 134). Miller's attempt to mitigate these costs is unsuccessful primarily because he has ignored a crucial part of the Crito where Socrates explicitly and clearly articulates his principle never to suppress inquiry or examination: $C r$ 46a-b. I consider Miller 1996 one of the better attempts to argue for a distinction between the views of Socrates and the views of the laws; I take the primary question of the dialogue as how to reconcile Socrates' own view as expressed in one part of the dialogue with Socrates' views implicitly expressed by his failure it examine in another part of the dialogue. Miller along with many other interpreters fails to recognize Crito's genuinely potent "argument” for escape: Crito proclaims that the time for argument is at an end and the time for action is at hand ( $\mathrm{Cr} 46 \mathrm{a})$.

losophy too appears to depend upon participation in the common good" (Blyth 1995, 64). Where Allen 1980 and others have Socrates choosing to obey the law because this is what seems best to his reason (see Cr 46b3-6), Blyth 1995 seems to have Socrates obeying the law because he cannot do otherwise. Further, Blyth seems to agree with Miller 1996 et al insofar as the laws' speech is merely a rhetorical remedy to Crito's philosophical ineptitude or "moral pathology" (Blyth 1996, 14): the laws' "speech is a gift by philosophy to the state, tailored to the state's capacities and needs, but it is not itself philosophy" (Blyth 1996, 17). I include Blyth among the latter group primarily due to the fact that he agrees with and supports Socrates' decision to remain in prison.

${ }^{22}$ Miller 1996, pp132-3. This possibility is aptly considered by Kraut 1984, pp44-53. 
Another, perhaps more significant interpreter who wants to explain away Socrates ostensible obedience is Richard Kraut. Kraut takes the speech of the laws far more seriously than do the more recent interpreters. Whereas Miller 1996 et al argue that the speech of the laws is unphilosophical, authoritarian rhetoric, Kraut 1984 argues:

The laws merely insist that when a citizen agrees to obey a law, he cannot break his agreement merely because it calls on him to suffer injustice. But since agreement is a matter of satisfaction and not mere residence, it is possible for a citizen to remain in the city and avoid making an agreement to obey an agreement to obey a law that he thinks does him injustice... if he disobeys, he must do so openly, and when summoned to court he must try to persuade the jury that he way right to disobey (Kraut 1984, 189).

A representative interpretation defending Socrates' obedience is Allen 1980:

The Crito maintains that legal obligation rests essentially neither on force nor on a set of rules fixed in the nature of things or the mind of God. It maintains that fidelity to the legal order is a moral obligation, and of such weight as to require Socrates to abide by an unjust sentence of death. This conclusion is defended by argument, an argument which rests on the two premises that one ought not return injustice for injustice or injury for injury, and that one ought to abide by agreements, given that they are just (111).

Allen's conclusion depends on the following qualification: "the authority of law extends only so far as agreement binds, and though agreement will bind to the suffering of injustice, in cannot bind to the doing of it" (112). Thus, for Allen, Socrates' commitment to the rule of Reason requires obedience to the law only because obedience to the law does not require Socrates to do injustice.

Most interpreters who argue that the speech of the laws is Socrates' position also fail to recognize the importance of Crito's final speech and Socrates' response. Unlike Miller, these interpreters do so generally because of a failure to recognize the tension and potential conflict between the first and second parts of the dialogue. Bostock 1990 is an exemplary article that focuses almost exclusively on the latter half of the dialogue. Bostock demonstrates that 
most contemporary attempts to avoid "authoritarianism" are untenable. While I find specific weaknesses in Bostock's reconstructions of the three main nonauthoritarian readings, I agree with Bostock's over-all approach and conclusion, namely "that the presumed expert is the Laws" and "For that reason, their advice must always be treated with the greatest respect" (Bostock 1990, 19-20). Perhaps the best recent interpretation that focuses exclusively on the latter half of the dialogue is Kahn 1989. Kahn demonstrates that there is no textual support for a Socratic notion of civil disobedience in the Crito.

Kahn is of particular help in identifying "the real puzzle of the Crito" by proving that the laws demand "total obedience" (Kahn 1989, 39-40). Kahn rightly notes that the ostensible disclaimer to obey or persuade - the key to Kraut 1984's reading_-means only "that Socrates has missed his chance not only to persuade the judges of his innocence but also to propose exile instead of death." ${ }^{33}$ So the real puzzle of the Crito is this: "why [do the laws] seem to require total submission to any legal command, a submission that apparently excludes the citizen's prerogative to refuse to perform an unjust act even when ordered to do so, when we know from the Apology that this is a prerogative that Socrates himself is morally bound to uphold?" With reference to the passage where the laws demand total obedience, Kahn wrongly thinks "there is from the philosophical point of view no hope of salvaging this passage" (Kahn 1989, 40). My interpretation supports Kahn's conclusion that there is no way to make the laws demand anything less than total obedience; I do not believe that this is a hopeless philosophical position and this paper is my attempt to make sense of such a position. The real puzzle is Socrates' own competing claims for absolute obedience to reason and absolute obedience to law. Recognizing this puzzle of conflicting principles, the first step in discovering the political philosophy of the Crito.

The first sort of interpretation, exemplified by Miller 1996, has the advantage of carefully addressing the dramatic structure of the whole dialogue and the potential conflict between Socrates' commitment to discursive examination and Socrates' obedience to law. The second sort of interpretation has the advantage of recognizing the seriousness of Socrates' obedience to law. Two re-

${ }^{23}$ Kahn 1989, p40n14. Contrast Kahn's understanding of the persuade-or-obey doctrine with Kraut 1984's version of the same: "A citizen will be justified in violating an order issued to him by his parent-city only if that order is in fact unjust. If the order does him an injustice he agreed to accept or risk, then he cannot rightly disobey it. The citizen who disobeys his city must, when summoned, persuade a jury that he was right to disobey. But if he was right yet fails in his efforts to show this to the jury, he has done no wrong" (68-9). 
cent interpreters, Metcalf 2004 and Polansky 1997 combine these advantages. Polansky's strategy "invites us to reflect upon the deep bond connecting the deliberations of individuals and the rule of law in political associations" (52); this bond is the "connection of logos and nomos" (52n7). The first half of the dialogue ( $\mathrm{Cr} 43 \mathrm{a}-48 \mathrm{~b})$ "emphasizes the very conditions of philosophical discussion;" it does so by "[defending] against skepticism about the worth of argument and [justifying] Socrates' personal commitment to listening to the argument that seems best" (Polansky 1997, 60). The second half of the dialogue ( $\mathrm{Cr} 48 \mathrm{~b}$ $54 \mathrm{e}$ ) "is an instantiation of what the first half argues for, the reliance upon the best available argument" (Polansky 1997, 67). Following Allen 1980, Polansky 1997 supports the seriousness of Socrates' decision to remain in prison because "Escaping the pronounced sentence...would be an inexcusable breach of just agreement” (67). I follow two main lines of Polansky's interpretation: a) the "appreciation of Socrates' arguments increases through attention to the whole course of the dialogue. Both halves of the argumentation are subtle and truly elenctic. Moreover, they fit together" (67). b) "In each half of the dialogue it is not so much a particular argument or law that is in question, but rather the whole basis and purpose of conversation and political life" (52). I agree with Polansky that we must interpret the dramatic and argumentative structure of both halves of the dialogue together; I agree that, read together, the two halves of the Crito address "the whole basis" of logos and nomos, Reason and Law. I disagree with Polansky about the relative priority of logos over nomos, at least in term of the Crito. In other words, I believe that Socrates remains in prison not because it would be unjust to do otherwise, but because Socrates recognizes the absolute authority of the personified laws. ${ }^{24}$

${ }^{24}$ Hannah Arendt rightly points out: "If authority is to be defined at all, then, it must be in contradistinction to both coercion by force and persuasion through arguments. (The authoritarian relation between the one who commands and the one who obeys rests neither on common reason nor on the power of the one who commands; what they have in common is the hierarchy itself, whose rightness and legitimacy both recognize and where both have their predetermined stable place)" (Arendt 1968b, 93). Polansky 1997 clearly has Socrates obey the laws because he has been and ought to have been persuaded by arguments: "The laws have established that Socrates or any thoughtful person has good grounds for accepting rule of law and legal procedure" (67, emphasis added). Following Arendt, I am not claiming that Socrates obeys the law under coercive force; rather, my thesis demonstrates that Socrates accepts a certain hierarchy of authority. This principle of authority obtains equally in the spheres of logos and nomos; indeed this principle is the common structure underlying both reason and law. 
Metcalf 2004 follows Polansky 1997 (among others) in addressing the Crito as a whole dialogue whose second part instantiates the first: "the shameargument of the dialogue, reminding Socrates of his rightful subjection to the laws, is precisely the articulation of what Socrates means when he vows to be persuaded by nothing else of what is his but the logos that appears best to him upon reflection [Cr 46b3-6]" (Metcalf 2004, 61-2). Yet, Metcalf convincingly argues that what gets instantiated or articulated in the second half of the dialogue is not the principle of autonomous reason, as Polansky 1997-perhaps despite himself - seems to suggest. ${ }^{25}$ The "shame-argument" is Metcalf's account of the Crito as a whole, wherein Socrates "prompts Crito to regard logos, rather than the doxa of the many, as the criterion of what is shameful. Thus, rather than setting aside Crito's concerns altogether, Socrates transforms their relationship

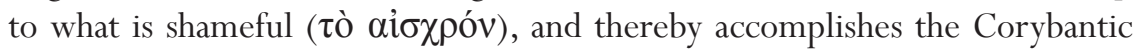
purging that is enacted over the dialogue as a whole" (Metcalf 2004, 50). For Metcalf 2004, logos is a criterion of shame just insofar as it is "a test of fidelity to one's defining commitments" (52):

the elenchos [Socrates] practices is not - at least, not first and foremost - a matter of refuting opinions or proposed definitions. Rather, it is the refutation of lives that do not live up to their defining agreements or commitments. The shame accompanying such an existentially-deep elenchos is the shame felt at one's lack of integrity (Metcalf 2004, 53).

${ }^{25}$ I say "despite himself" because Polansky, more than most, is acutely aware that Socratic elenchus is not reducible to anything like pure reason or logical refutation; see, e.g., Polansky 1985, Polansky and Carpenter 2002 and [reference omitted for Blind Review]. Polansky agrees with Metcalf that Socratic elenchus is essentially ad hominem in character. Yet, even Polansky may fall victim to what Metcalf calls "the Kantian conception of rational autonomy [that] remains so powerful an influence upon interpretations of the Crito" (Metcalf 2004, 61). Thus, for Polansky, what is instantiated in the second half of the dialogue is "the reliance upon the best available argument" not Socrates" "rightful subjection to the laws;" when Polanksy says that "the condition for receiving benefit from the city [is] that one accedes to just orders" (Polansky 1997, 64), it is hard not to imagine that he has something like autonomous reason in mind as that which determines the justice or injustice of orders with recourse to "the best available argument." On my view, one accedes to the commands of the personified laws not because they seem just to one's reasoning, but because it is the laws who command. Nevertheless, the concept of autonomous reason influences Polansky far less than most; especially less than those interpreters who want to explain away Socrates' obedience as a rhetorical ploy, e.g., Miller 1996, Weiss 1998, and Harte 1999. 
Metcalf draws our attention to two points that contribute decisively to my interpretation of the Crito: First, Crito's concerns - while overly respectful of the opinions of the many - are far too serious to be simply set aside or sophistically assuaged. ${ }^{26}$ Metcalf is nearly alone among interpreters (excepting perhaps Blyth 1995 and 1996) to recognize the potency of Crito's arguments, especially from $\mathrm{Cr} 45 \mathrm{c} 1-46 \mathrm{a} 8$. Second, what are really at stake in the Crito are the fundamental principles from which all deliberation and action proceed:

Socrates is being shown the unliveability of the life he would have spared for himself by escaping into exile. This deliberative instance of elenchos, like all forms of elenchos, is essentially ad hominem, for the life in exile is shown to be unliveable in light of Socrates' defining commitments, e.g., his commitment to Athens, his commitment to philosophy, his commitment to his friends and family, his commitment to himself as someone who is distinguished by the peculiar excellence of soul, and in general his commitment to living well rather than simply staying alive (Metcalf 2004, 59).

26 "The sense of shame that reminds [Socrates] of his subjection to the laws is not merely an 'external' matter of conforming his conduct to the expectations of the hoi polloi, nor is it entirely indifferent to Crito's concerns about the 'unmanliness' with which Socrates appears to have acted, or about matters of reputation and the upbringing of his children, etc" (Metcalf 2004, 60). Cf. Blyth 1995, p58. Polansky 1997 touches upon, but never develops, the interpretation of Crito's objections that I develop below. Polansky recognizes that Crito's final "argument" is really an injunction that argument is no longer an appropriate means of answering their questions; for Polansky this is a form of "skepticism" (55). Polanksy rightly says: "What we have here is some indication of the limit of argumentation. There are inevitably problems with grounding reliance upon argument in argument." Polansky naively continues "But if it is agreed that the soul is really crucial and that some conditions of the soul are superior to others and that some arguments contribute to these better conditions, then argument can defend itself and Socrates must adhere to this argument in the face of any temptations to do otherwise" (Polansky 1997, 60). Fair enough; what Polansky does not see is that the real potency of Crito's objections is to challenge the antecedents of Polanky's conditional statement on non-argumentative grounds. The real potency of Crito's final "arguments" is that he clearly suggests that certain circumstances may require that we end deliberation prior to definitive conclusion; thus, in principle no deliberation is capable of arguing that the present ones are not such circumstances. What Plato is invoking through Crito's objection is the principle of authority: someone must decide on the limits of argument in order for argumentation to be meaningful at all. 
These defining commitments or fundamental principles are not general, legal theory under which Socrates' particular case is subsumed. ${ }^{27}$ Rather, the laws address themselves specifically to Socrates and the principles from which his life is governed. To paraphrase after my own purposes, the central, defining commitment through which all others can be understood is Socrates' commitment to be ruled, whether by the best argument or by the laws of Athens.

This brief survey of some of the relevant scholarship on the Crito has - albeit somewhat artificially_identifies two sorts of interpretations: those which argue that Socrates does not and ought not dogmatically obey the laws of Athens, and those which argue that Socrates ought to obey these laws. Thinking about recent work on the Crito in these terms has the advantage of revealing a tension between the first half and the second half of the dialogue, a tension common to nearly all interpretations. Perhaps most importantly, this schema reveals that heretofore the most pressing question of the dialogue has been 'What is it reasonable for Socrates to do?' Some argue that it is reasonable not to obey the laws; others argue that it is reasonable to obey the laws. I have concluded my survey with Metcalf 2004 because this interpretation points to a slightly different question: Who has the authority to determine what is reasonable?

\section{Preliminary Conclusions}

The crucial and unanswered question is "has the city done injustice to [Socrates], and has it incorrectly decided its judgment?" (Cr 50c1-2). Crito responds that it seems so. Rather than answering the question, or arguing that he has not been wronged by the city, or even examining the justice of remaining in

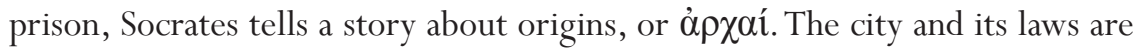

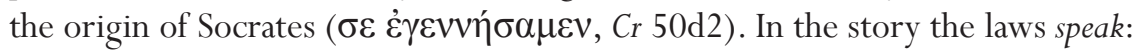
was not it "on account of us that your father took your mother in marriage and begat you?" ( $\mathrm{Cr} 50 \mathrm{~d} 2-3)$. The laws ask Socrates if he finds fault with these marital laws or with the laws according to which he was nurtured and educated;

${ }^{27}$ Contrast this with Kraut 1984: "Since [Socrates] applauds the speech of the laws, he presumably interprets it in a way that leaves room for his principle that one must never act unjustly. Therefore, we too ought to look for parts of that speech that open the door to justified disobedience. And once we find them, we must see how they can be integrated into the rest of the speech to form a consistent theory" (24). With Metcalf, Kahn 1989 finds "the argument of the Crito [to be] ad hoc and ad hominem. It is not an argument for obedience to law in general: it applies specifically to this man and this law" (35). 
Socrates replies that he finds no fault with these laws, nor with the laws according to which he was trained in music and athletics. The laws then ask Socrates:

Since you were born, nurtured and educated, could you possibly be able to say that your are not first our child and slave, both you yourself and your ancestors? And if this is just how

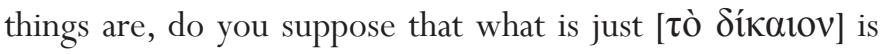
based upon equality [ $\dot{\varepsilon} \xi$ í $\sigma 0 v]$ between you and us and that whatever we attempt to do to you, do you suppose it just

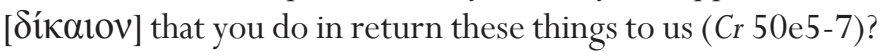

The laws claim that their right to destroy Socrates does not give Socrates the right to destroy the laws. There is a crucial inequality between the ruler (the Laws) and the ruled (Socrates), this, despite the fact that Socrates explicitly frames their relationship in terms of agreement. ${ }^{28}$ In a very important way, this inequality is like an inequality suggested by Crito's pragmatic injunction.

Someone must decide when practical circumstances demand action in the absence of definitive deliberation. This is an essentially human decision and it cannot be governed by reason because it is a decision to suspend reason, and by analogy law. Such an exceptional situation ${ }^{29}$ requires someone competent to decide what counts as the normal situation in which reason and law ought to rule. By speaking, the Laws choose or discern what counts as marriage, what count as families and children, what counts as nurture and education thereof. While it may be very interesting to ponder the way that the laws beget Socrates, what is most important for my present purposes is the clear implication that Socrates' very being is "on account of" the Laws. The argument emphasizes possibility:

${ }^{28}$ It is an interesting question just how Socrates' "agreement" with the laws is or is not like the modern notion of contract-theory. Kahn rightly argues that it is a "mistake" to read "into the Crito a contract theory in the classical sense of Hobbes and Rawls" (Kahn $1989,30)$. There is at least this obvious difference between these two notions of agreement: Socrates' contract is not based upon the equality of the contracting parties. In addition, I do not want to address here the analogy of parents to political authority and children to those ruled. This is perhaps one of the most pervasive and important analogies in political philosophy, ancient, modern, or otherwise. This analogy gets at the principle of all political philosophy: human nature. Thus for example, John Locke recasts the relationship of parents to children in explicitly contractual terms in order to abide by the fundamental analogy and use it to make contractual government natural, or at least seemingly so. See Locke 1980, chapters 6-8.

${ }^{29}$ For more on the nature of "the exception" and the corresponding notion of Sovereignty, see Schmitt 1985. 
Since Socrates was "born" it is impossible for Socrates "to be able to say that that [Socrates] is not" what he is. The Greek emphasizes this argument from pos-

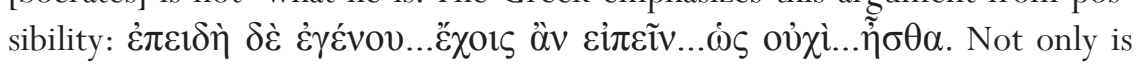
the verb 'to have' used with the infinitive to mean 'be able,' but the same verb is used in the optative with ớ $v$ to designate potential. Thus, a negative response to the question clearly implies this: Only because the Laws have first discerned what counts as 'being born' is it possible for Socrates to say anything; indeed, only because the laws have first determined what counts as 'coming to be' is it possible for Socrates to be what he is, namely an Athenian son and educated man worthy of even speaking to the Laws.

For Socrates, some authority must exercise the competence to determine the boundaries of the normal situation in which reason and law rule absolutely. Socratic philosophy is possible only within these determinate boundaries. Insofar as Socrates is the ideal practitioner of philosophical expertise it is impossible for him to determine the boundaries of philosophy, because doing so is external to Socratic philosophizing. Thus, Socrates accepts the speaking laws as an external authority of logos and nomos. By correctly interpreting the first and second parts of the Crito, we can see that Socrates commits himself to doing nothing outside of these rules; this is Socrates' commitment to the absolute rule of reason and law. Some authority must determine the boundaries of these rules. This authority - essentially external to reason and law — is most clearly exemplified by the personification of the laws in the Crito. The fact that the laws speak makes these laws essentially different from actual laws. Laws are universal, just as deliberative or discursive reason is universal; as such, laws cannot speak. Speech, especially in this case, is the expression of human judgment about particular individuals and particular circumstances; to speak is what laws cannot do. It is only in virtue of the fact that the laws do render judgment about whether Socrates counts as a member of the political community that makes them deserving of the absolute obedience that Socrates offers. If these laws did not speak, then their being just would be a legitimate and necessary question; this would be a question as to whether the "laws" of Athens are really the laws of Athens. Yet, since the laws do speak, there is no question about their authority or justice. Plato nowhere suggests that the laws of Athens are not laws. What it is that is speaking to Socrates at the end of the Crito is the laws; as such, they must be obeyed. Moreover, it is for just this reason that Socrates explicitly refuses to answer the question about their alleged injustice: to do so would be either to assert a contradiction, 'the Laws may not be laws,' or to reject the definition of law. We can clearly see why Socrates would be unwilling to do the former; so 
why is Socrates unwilling to challenge the definition of law according to which to disobey one is to destroy law entire?

This is a particularly difficult question in light of the fact that Socrates spent most of his life examining definitions, of justice, of courage, of temperance, etc. Socrates refuses to investigate the definition of 'law' in this context because he is face to face with a living and talking law. I fully grant that in different circumstances Socrates would have argued against the definition of law as 'that which must be obeyed'. However, in the presence of particular things that are unquestionably laws, Socrates cannot challenge the definition of law because to do so would not be merely to deliberate about the essence of law; rather, to do so would be to contest the status of this particular thing here, to claim that they are incorrectly named 'laws'. The question of whether this particular thing here is or is not a law is a question of an entirely different order than the question of what law is.$^{30}$ This is, however, only to begin an explanation of why Socrates merely accepts the definition of law as that which must be obeyed; what cannot be denied is that Socrates does just this.

One of Hannah Arendt's most important insights on authority is that it must be in some sense 'outside' that over which it has authority (Arendt 1968b, 97-8, 110-11). The crucial idea is that whatever has authority must rule without recourse to violence or argument. It is true that persuasion by argument is what the authority of reason commands at Crito 46b. However, that Socrates should be ruled by argument instead of greed, or lust, or whim, cannot be justified through persuasion or argument. Rather, reason presupposes an authority that stands outside reason, the authority that establishes that reason ought to rule. It is in just this sense that reason and law are structurally similar: As there can be no reason to believe that reason is the best way to proceed, so there can be no law that would establish that law should rule. Law requires something outside of law both to establish the boundaries within which it applies and to make decisions about the application of the law in particular instances. Some authority, in the case of reason or law, must decide on the limits of their applicability, or the boundaries only within which can either function. In the Crito, it seems to be the speaking laws that exercise this authority.

The dependence on an external authority is the common structural feature of reason and law; and, the principle of principles is that Socrates recognizes

${ }^{30}$ I find it most helpful to think of these different "orders" with recourse to the distinction between metaphysics and epistemology, respectively; my understanding of this distinction is most indebted to Kripke 1980, pp. 35-49. 


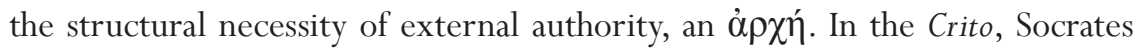
refuses to question the definition of law because, in the presence of the laws to do so would be to claim for himself the authority to define law...this would be hubris.

The entire Socratic project depends upon the principle of exteriority: there must be something outside of our definitions according to which our definitions are true and false, there must be something outside of law to make decisions about particular cases; and, most shockingly, there must be something outside of reason that authorizes the superiority of reason over force. From this perspective of outside, reason and law are remarkably similar: they are internally consistent systems of evaluation that are entirely dependent upon some external decision about their own limits or conditions. This decision is fundamentally political and necessarily human. Plato reveals Socrates' commitment to this principle of authority by contriving a situation, the Crito, in which Socrates is simultaneously committed to the rule of reason and the rule of law. The only way to understand this contrivance - and not let Socrates' obedience to law contradict his obedience to reason - is to realize that reason and law are alike precisely as systems of universal rules essentially dependent upon external authority personified here by the speaking laws. Socrates rightly acquiesces to this authority because his philosophical life of inquiry and his political life as a citizen of Athens depend upon it.

\section{References}

Allen, R. E. 1980. Socrates and Legal Obligation. Minneapolis: University of Minnesota Press.

Arendt, H. 1968a. Between Past and Future: Eight Exercises in Political Thought. New York: Penguin Group. . 1968b. 'What Is Authority?' in Arendt 1968a, 91-141.

Blyth, D. 1995. 'Plato's “Crito” and the Common Good.' Ancient Philosophy 15: 45-68.

. 1996. 'What in Plato's “Crito” Is Benefited by Justice and Harmed by Injustice.' Apeiron 29: 1-19.

Bostock, D. 1990. 'The Interpretation of Plato's Crito.' Phronesis 35: 1-20.

Brouwer, M. and R. Polansky 2004. 'The Logic of Socratic Inquiry: Illustrated by Plato's Charmides.' in Karasmanis 2004, 233-245.

Brown, H. 1992. 'The Structure of Plato's “Crito”.' Apeiron 25: 67-82. 
Harte, V. 1999. 'Conflicting Values in Plato's "Crito”.' Archiv fuer Geschichte der Philosophie 81: 117-147.

. 2000. review of Socrates Dissatisfied: An Analysis of Plato's Crito by R. Weiss. Classical Philology 95: 362-366.

Kahn, C. H. 1989. 'Problems in the Argument of Plato's Crito.' Apeiron 22: 2943.

Karasmanis, V. ed. 2004. Socrates: 2400 Years since His Death. Delphi: European Cultural Centre of Delphi.

Kraut, R. 1984. Socrates and the State. Princeton, N.J.: Princeton University Press.

Kripke, S. A. 1980. Naming and Necessity. Cambridge, Mass.: Harvard University Press.

Lane, M. S. 1998. 'Argument and Agreement in Plato's “Crito”.' History of Political Thought 19: 313-330.

Locke, J. 1980. Second Treatise of Government. C. B. Macpherson ed. Indianapolis: Hackett Publishing Company.

Metcalf, R. 2004. 'The Elenctic Speech of the Laws in Plato's Crito.' Ancient Philosophy 24: 37-65.

Miller, M. 1996. "'the Arguments I Seem to Hear": Argument and Irony in the Crito.' Phronesis 41: 121-137.

Polansky, R. 1985. 'Professor Vlastos' Analysis of Socratic Elenchus.' in Oxford Studies in Ancient Philosophy 3, 247-259. . 1997. 'The Unity of Plato's Crito.' Scholia 6: 49-67. and M. Carpenter 2002. 'Variety of Socratic Elenchi.' in Scott 2002, 89-100.

Schmitt, C. 1985. Political Theology : Four Chapters on the Concept of Sovereignty. G. Schwab trans. Cambridge, Mass.: MIT Press.

Scott, G. A. ed. 2002. Does Socrates Have a Method? : Rethinking the Elenchus in Plato's Dialogues and Beyond. University Park: Pennsylvania State University Press.

Vlastos, G. 1980. The Philosophy of Socrates : A Collection of Critical Essays. Notre Dame, Ind.: University of Notre Dame Press.

Weiss, R. 1998. Socrates Dissatisfied: An Analysis of Plato's Crito. New York: Oxford Univ Pr.

Woozley, A. D. 1979. Law and Obedience : The Arguments of Plato's Crito. Chapel Hill: University of North Carolina Press. . 1980. 'Socrates on Disobeying the Law.' in Vlastos 1980. 